\title{
Jogpolitika
}

\author{
Bencsik András-Barta Attila*
}

\section{A települési önkormányzatok szerepe a környezetvédelmi igazgatás átalakult rendszerében**}

\author{
közigazgatás - környezetvédelem - helyi önkormányzatok - \\ településfejlesztés - építésügy
}

\begin{abstract}
Napjainkban általánosan elfogadott, hogy nélkülözhetetlen a környezettel való tudatos, felelősségteljes bánásmód. Korunk államainak müködését egyre inkább új dimenzióba helyezi a legtágabb értelemben felfogott globalizáció jelensége. A globalizálódó és digitalizálódó világ sajátosságai, így egyebek mellett a (kiber)terrorizmus fenyegető jelenléte, a munkanélküliség vagy éppen a járványok terjedése, a migrációs folyamatok tömegessé válása vagy az országokon átívelő környezetszennyezések olyan új világot körvonalaznak, amelyben egymagában sem az állam, sem az egyén, sem a társadalom nem tud eredményesen fellépni. ${ }^{1}$ Mindezek alapján a környezetvédelem területén is a komplexitás és a pluralitás szükségessége fogalmazódik meg az egyes államok szintjén, a jelzett tendenciák közepette az állam környezetvédelmi fellépésének figyelemmel kísérése és folyamatos fejlesztése pedig szükségszerü.
\end{abstract}

* Dr. Bencsik András egyetemi adjunktus, Pécsi Tudományegyetem Állam- és Jogtudományi Kar Közigazgatási Jogi Tanszék, bencsik.andras@ajk.pte.hu; Dr. Barta Attila egyetemi adjunktus, Debreceni Egyetem Állam- és Jogtudományi Kar Közigazgatási Jogi Tanszék, barta.attila@law.unideb.hu.

** A tanulmány a „Helyi önkormányzati szerepek és eszközök az ökológiai fenntarthatóság megvalósításában” című, a Nemzeti Kutatási, Fejlesztési és Innovációs Hivatal által támogatott, K 115530 nyilvántartási számú OTKA projekt keretében készült. A projekt bemutatására lásd FODOR László-BARTA Attila-FónAI Mihály-BÁNYAı Orsolya: Települési környezetvédelem Magyarországon - Egy kutatás előfeltevései. Tér és Társadalom, 2016/3, 19-39. A kézirat lezárásának időpontja 2016. augusztus.

1 ÁDÁm Antal: A magyar alkotmányból hiányzó alapértékekről. Közjogi Szemle, 2009/1, 4. 
A felismerés, mely szerint tágabb és szükebb világunk átalakul, ${ }^{2}$ sorra vezet újabb és újabb lépésekhez, melyek valamilyen formában közigazgatási szerveket is érintenek. Ennek megfelelöen a hatályos magyar közjogi szabályozás a környezetvédelemmel összefüggő feladatokat és rokon területeket az államszervezet több szintje és szereplöje között osztja meg. ${ }^{3}$ A környezettel való tudatos és felelösségteljes gazdálkodásnak, mint számos alrendszeren átívelő, úgymond keresztülfekvő tevékenységnek a területi-helyi államigazgatási szervek, valamint a települési önkormányzatok különösen fontos résztvevői. ${ }^{4}$

Utóbbiak szerepének vizsgálatát indokolja többek között az, hogy nemcsak a helyben generált konfliktusok, hanem a térben és idöben elhúzódó, globális környezethasználatból fakadó hatások egy része is jelentkezik lokálisan, tehát valamely település közigazgatási területén. Ez számos helyi feladatot generál, amelyek rendezéséhez az önkormányzatok jogi (például rendeletalkotás, hatósági eljárások) és nem jogi eszközöket (mint a képzés, környezeti tudatformálás, ${ }^{5}$ civilszervezetek támogatása, helyi gazdaságszabályozás) egyaránt igénybe vehetnek.

Jelen tanulmányban a környezetvédelmi szakigazgatási ágazat feladat- és hatásköreit érintő, általunk fontosnak ítélt változásokat érintjük, arra is tekintettel, hogy az elmúlt években (évtizedben) irányát, terjedelmét, eszközrendszerét és volumenét tekintve intenzívebbé vált a környezetvédelem tekintetében az állami felelősség és aktivitás. Megkerülhetetlen ezzel összefüggésben az alkotmányjogi háttér és a mai környezetvédelmi intézményrendszer rövid áttekintése is, tekintettel az államigazgatási és az önkormányzati alrendszer között az elmúlt években történt - témánkat érintő - kompetenciaváltozásokra. Célunk ennek megfelelően a végbement átalakítások értékelése, valamint a lehetséges fejlesztési irányok érzékeltetése. Áttekintésünk során a közigazgatási jogi megközelítésnek adunk elsöbbséget. Jelen munka egy kutatási projekt része, ennek megfelelően nem törekszünk a tárgykör teljes spektrumának ismertetésére. Ehelyett mindössze két, a helyhatóságok szintjét érintő közigazgatási részterületet (építésügy és településfejlesztés) villantunk fel, alapvetően azok környezetvédelmi kötődéseit vizsgálva. Terveink szerint az áttekintést később más szakigazgatási területekkel fogjuk bővíteni.

\section{A hatályos környezetvédelmi intézmény- és feladatmegosztási rendszer jellegzetességei Magyarországon}

A minket körülvevő természetes és mesterséges környezet védelme csak akkor lehet eredményes, ha abban az érintettek minél szélesebb köre akar és képes részt

2 Éghajlatváltozás 2014. Szintézisjelentés, döntéshozói összefoglaló. http://www.ipcc.ch/pdf/reports-nonUNtranslations/hungarian/ar5-spm-syr.pdf (2016. 06. 29.). Továbbá a KSH 2016-os kiadványa Magyarországról http://www.ksh.hu/docs/hun/xftp/idoszaki/mo/mo2015.pdf, a 171. oldaltól kezdődő rész.

3 BÁNDI Gyula: Környezetvédelmi igazgatás. In: Lapsánszky András (szerk.): Közigazgatási jog. Fejezetek szakigazgatásaink köréböl. II. kötet. CompLex, Budapest, 2013, 498-501.

4 FODOR-BARTA-FÓNAI-BÁnYAI: i. m., 23-25.

5 SzABó György: A települési önkormányzatok környezetvédelmi feladatai. Debreceni Egyetem, Debrecen, 2008, 20. 
vállalni. Másképp kifejezve, anyagi világunk élhető szintjének megőrzése sokszereplős tevékenység, ami a (köz)jogi szabályozásban is egyértelmüen leképeződik. Amennyiben ugyanis környezetünk védelmét önálló szakigazgatási területként közelítjük meg, azzal szembesülünk, hogy számos más kérdéskörrel (építésügy, településfejlesztés, bányászat, hulladékgazdálkodás, földügyi igazgatás stb.) intenzív kapcsolatban áll, ami a környezetvédelem keresztülfekvő, integratív jellegével magyarázható. ${ }^{6}$ Mivel a kapcsolódó feladat- és hatáskörök számos aktor között oszlanak szét, az intézményrendszer sokszereplös.

Magyarország Alaptörvénye három aspektusban közelít a környezetvédelem témaköréhez: a fenntartható fejlődésen, a jövő nemzedékek lehetőségeinek védelmén és a nemzeti erőforrásainkkal való hosszú távú felelős gazdálkodáson keresztül, amely kiegészül a fenntartható társadalom kialakítása érdekében szükséges nemzetközi és belső összefogás igényével. ${ }^{7}$ Ebben a szellemiségben nem csupán egyes természeti erőforrások (mint a vízkészlet, a biológiai sokféleség) védelmét teszi mindenki kötelességévé, de az ún. fenntarthatóság eszméjét is beemeli védendő értékei közé. ${ }^{8} \mathrm{Az}$ elöbbieken túl a jogalkotó többek között a környezet védelmén keresztül is igyekszik segíteni a testi és lelki egészséghez való jog megvalósulását, valamint általánosságban elismeri és érvényesíti mindenki jogát az egészséges környezethez. ${ }^{9}$ Az Alaptörvény által lefektetett kereteket számos jogszabály tölti meg tartalommal, melyek közül valamennyi ismertetésére ezen a helyen nincs lehetöségünk. Emiatt a továbbiakban kizárólag olyan jogszabályi csomópontokra utalunk, amelyek érdemben határozzák meg a környezet védelmét, valamint a hozzá kapcsolódó szakigazgatási területek jellegzetességeit.

A környezet védelmének általános szabályairól - ágazati kódexként - az 1995. évi LIII. törvény (a továbbiakban: Kvt.) rendelkezik. A Kvt. rendeltetése, hogy kialakítsa azt a vázat, amely már kellően konkrét ahhoz, hogy az Alaptörvényt kibontsa, ugyanakkor képes az egyes környezeti elemek (levegö, víz stb.) és a kapcsolódó szakigazgatási területek (mint a közlekedés, ipari tevékenység) speciális rendelkezéseinek a fogadására is. Nem véletlen, hogy a törvény által meghatározott környezetvédelmi definíció meglehetősen tág („olyan tevékenységek és intézkedések összessége, amelyeknek célja a környezet veszélyeztetésének, kárositásának, szennyezésének megelőzése, a kialakult károk mérséklése vagy megszüntetése, a károsító tevékenységet megelöző állapot helyreállitása"), ${ }^{10}$ hiszen alkalmasnak kell lennie valamennyi releváns aktivitás befogadására. Ez is azt támasztja alá, hogy a fenti magatartások nem kizárólag közjogi aktorok által valósíthatók meg, a környezet védelme ettöl öszszetettebb tevékenység, ahol a Kvt. alapján az állami szervek, a helyi önkormányza-

6 Ezzel összefüggésben lásd továbbá FOdoR László: A helyi szabályok eltérése a központi előírásoktól környezetvédelmi megfontolások. Jogtudományi Közlöny, 2016/7-8 [a továbbiakban: FodoR (2016)], 354, 362-364; valamint FülöP Sándor: Környezetvédelmi eljárásjog. PhD-értekezés, Debrecen, 2012. http://jog. unideb.hu/media/documents/doktori_nyilvanosvita/fulop-ertekezes.pdf (2016. 11. 23.).

7 Ehhez bővebben lásd BÁNDI Gyula: A környezethez való jog értelmezése a fenntartható fejlődési stratégia és az Alaptörvény fényében. Acta Humana, 2013/1, 68.

8 HoRvÁtH Gergely: Környezetvédelem. NKE, Budapest, 2014, 8; Alaptörvény $P$ ) és Q) cikk.

9 Elöbbi kapcsán lásd az Alaptörvény XX. cikkét, utóbbi kapcsán a XXI. cikket.

10 Kvt. 4. § 32. pont. 
tok, a természetes személyek és szervezeteik, a gazdálkodást végző szervezetek és mindezek érdekvédelmi szervezetei, valamint más intézmények együttműködni kötelesek. ${ }^{11}$ Ebben a megközelítésben az állami intézményrendszernek alapvetöen három feladata van. Egyfelöl a jogi szabályozás kialakítása, másfelöl a környezet védelmével összefüggő jogok és kötelezettségek megállapítása, kontrollálása, végezetül a környezet védelmének szervezése és irányítása.

Az alábbiakban kifejezetten csak a közigazgatási szervek környezetvédelemmel összefüggő legfontosabb kompetenciáit ismertetjük, ${ }^{12}$ elsőként az államigazgatási, majd az önkormányzati teendőkre kitérve.

\section{1. Államigazgatási kompetenciák}

Formális szempontból vizsgálva a magyar környezetvédelmi intézményrendszer plurálisnak tekinthető, ugyanakkor a jogalkotó az ezzel összefüggő feladat- és hatáskörök megvalósitását alapvetően állami (államigazgatási) keretek között képzeli el. Ezt a megállapítást a tételes jogi szabályozás ama rendelkezésével kívánjuk alátámasztani, amely a környezetvédelmi kompetenciák alapozó rendelkezésének tekinthetö. A Kvt. 37. § (2) bekezdése szerint „[a]z állam biztositja a környezet védelméhez füződő állampolgári jogok és a más államokkal vagy nemzetközi szervezetekkel kötött környezetvédelmi egyezmények, szerződések érvényesülését”. A törvény ezt követően kísérletet tesz az állami felelösség tartalmának a konkretizálására, amelynek megfelelően az állam környezetvédelmi feladatai közé tartozik a környezetvédelmi követelmények érvényesítése az állam más irányú feladatai ellátása során; a környezetvédelem kiemelt feladatainak meghatározása; a környezetvédelmi célok elérését szolgáló jogi, gazdasági és műszaki szabályozórendszer megállapítása; a környezetvédelmi államigazgatási feladatok ellátása; valamint a környezetvédelem gazdasági-pénzügyi alapjainak biztosítása. ${ }^{13}$

A Kormány - Magyarország Alaptörvénye értelmében - a közigazgatás legfelső szintű irányítója, amely megfogalmazásból az is következik, hogy - szervezeti és tartalmi szempontból egyaránt - meghatározó befolyást gyakorol a magyar közigazgatás működésére, így természetszerüen a környezetvédelmi igazgatásra is. A törvényi szabályozás értelmében „[a] Kormány irányítja az állami környezetvédelmi feladatok végrehajtását, meghatározza és összehangolja a minisztériumok és a Kormánynak közvetlenül alárendelt szervek környezetvédelmi tevékenységét". ${ }^{14}$ A környezetvédelem keresztülfekvő jellegét juttatja kifejezésre a fejlesztéspolitika és a környezetvédelem kapcsolódása, amely a Kvt. rendelkezéseiben is visszaköszön: egyrészt „[a] Kormány az éves költségvetés elöterjesztésekor javaslatot tesz a Programban kitüzött célok megvalósitását szolgáló pénzeszközökre", valamint

11 Kvt. 10. §(1)

12 Ezzel kapcsolatban a korábbi szakirodalomból érdemes még átolvasni: Kilényi Géza (szerk.): A Közigazgatási Jog Nagy Kézikönyve. CompLex, Budapest, 2008, 1224-1227.

13 Kvt. 38. §.

14 Kvt. 41. § (1). 
„[a] kormányzati fejlesztési feladatok meghatározása során a Kormány érvényesíti a környezetvédelem követelményeit". ${ }^{15} \mathrm{~A}$ Kormány környezetvédelmi jellegű feladatai közé tartozik ennek keretében:

a) „a nemzetközi szerződésekből adódó környezetvédelmi kötelezettségek teljesitése és jogok érvényesitése;

b) a környezetvédelem követelményeinek megfelelö környezetkímélö vagy környezetbarát termékek előállitásának, technológiák, létesítmények megvalósitásának, elterjedésének elősegítése;

c) a jelentős környezetkárosodások, illetve a rendkivüli környezeti események (beleértve a Magyarország területén folytatott hadgyakorlatot is) következményeinek felszámolása, ha a kötelezettség másra nem háritható; ${ }^{16}$

d) az állam környezeti kártérítési kötelezettsége fedezetének biztositása és a kötelezettségek teljesitése". ${ }^{17}$

A Kormány komplex szervezetirányító és a környezetvédelmi politikát alakító tevékenységének segitésére hozta létre a jogalkotó az Országos Környezetvédelmi Tanácsot, amely javaslattevő, tanácsadó, véleményező szerv, „a környezetvédelem széles körü társadalmi és tudományos, szakmai megalapozása érdekében". A testület egyik tagja a környezetvédelemért felelős miniszter, további tagjai egyenlő arányban a környezetvédelmi társadalmi szervezetek saját eljárási rendjükben választott képviselői, a szakmai és gazdasági érdekképviseleti szervek választott képviselői, illetve a tudományos élet reprezentánsai, akiket az MTA elnöke bíz meg. ${ }^{18} \mathrm{~A}$ tanács feladatköre nem lép túl a véleményezés, javaslattétel, állásfoglalás keretein. ${ }^{19}$

Nem szorul igazolásra az a megállapítás, miszerint a Kormány felelősségi körébe utalt feladat- és hatáskörökön kívül egyéb, konkrét aktivitások is szükségesek az állam környezetvédelmi feladatainak ellátásához, így szükséges szólni a környezetvédelemért felelős miniszter ágazatirányító tevékenységéröl. A miniszter (a hatályos szabályozás szerint a földművelésügyi miniszter) egyebek mellett irányítja a feladatkörébe utalt környezetvédelmi tevékenységeket, a nemzetközi szerződésekböl adódó környezetvédelmi feladatok végrehajtását, a feladat- és hatáskörébe tartozó környezetvédelmi igazgatást. Elemzi és értékeli a környezet állapotát és védelmének helyzetét, a természeti erőforrásokkal való gazdálkodás folyamatait, a környezeti veszélyhelyzet kialakulásának megelözését, közremüködik a természeti erőforrások felhasználására vonatkozó szakmapolitikai koncepciók kialakításában. ${ }^{20}$

15 Kvt. 41. § (2) és (3) bekezdései.

16 A Kormány mögöttes helytállási kötelezettsége nyomán az állam közvetett felelőssége általánossá válhat. Ennek gyakorlati intézményeként szolgálnak a környezetvédelmi kárelhárítási alapok. Bándi Gyula: Környezetvédelmi igazgatás. In: Fazekas Marianna (szerk.): Közigazgatási Jog Különös Rész. Osiris, Budapest, $2011,116$.

17 Kvt. 41. (5) a)-d) pont.

18 Ennek részletesebb tárgyalásához lásd BÁnDı Gyula: Környezetvédelmi igazgatás. In: Lapsánszky András (szerk.): Közigazgatási jog. Fejezetek szakigazgatásaink köréből. Il. kötet. CompLex, Budapest, 2013, 483. A kép árnyalásaként kiemeljük, hogy a tagok között - a normatív szabályozással ellentétben - kezdettől fogva nem találhatók meg az önkormányzati szövetségek delegáltjai.

19 Kvt. 45. § (1)-(7) bekezdései.

20 Kvt. 42. §. 
A közigazgatás alacsonyabb szintjein tipikusan végrehajtó tevékenység zajlik. ${ }^{21}$ 2016-ban Magyarországon környezetvédelmi hatóságnak az államigazgatási oldalon vagy a földmüvelésügyi minisztert, vagy 2017. január 1-jei megszünéséig az Országos Környezetvédelmi és Természetvédelmi Föfelügyelőséget (röviden: OKTF), ${ }^{22}$ vagy a fővárosi/megyei kormányhivatalokat, ${ }^{23}$ illetöleg azok járási hivatalait, esetleg az Országos Meteorológiai Szolgálatot (a továbbiakban: OMSZ) tekintjük. Az önkormányzati szervek közül ugyanakkor vagy a (fö)polgármester, vagy a (fö) jegyző járhat el környezetvédelmi hatóságként. ${ }^{24}$

A természetvédelmi hatóságok rendszere ezzel szinkronban van, azonban egyszerübb, miután a miniszteren, valamint az OKTF-en kívül csak a területi kormányhivatalt (járási hivatalok nélkül), valamint a jegyzőket nevesíti ebben a körben a jogalkotó. ${ }^{25}$ Környezetvédelmi igazgatási szervnek ma kizárólag államigazgatási szervek tekintendők, úgymint az OKTF, a területi kormányhivatal, a tervek szerint 2017. január 1-jén megszünő Herman Ottó Intézet, valamint az OMSZ. ${ }^{26} A$ természeti területek természetvédelmi kezeléséért felelös szerv a fentiektöl elkülönül, ezeket a feladatokat a nemzetipark-igazgatóságok (NPI) látják el, ahogy a természetvédelmi örszolgálat is ezek részeként müködik. ${ }^{27}$

\section{2. Önkormányzati feladat- és hatáskörök}

Mielőtt a magyar helyi önkormányzatok kapcsolódó (szak)feladatait áttekintjük, érdemes röviden kitekinteni arra, hogy az elmúlt években milyen változások következtek be a magyar önkormányzatokat illetően. Mivel a 2010. évi választások után a Magyar Államnak és végrehajtó apparátusának a megújitása, megerősitése általános törekvéssé vált, ${ }^{28}$ a civil és rendészeti közigazgatás is több elemében (szervezetében, személyzetében, eljárásában) megújult, illetve átalakult. Ezzel szinkronban a helyi önkormányzatok államszervezeten belüli helyzete, alkotmányos kerete is átalakult. ${ }^{29} \mathrm{Az}$ újragondolt területi és települési szintű igazgatásban - elsősorban a hatékonyság és eredményesség jegyében - az önkormányzatok feladatai módosul-

21 Lásd a 71/2015. (III. 30.) Korm. rendeletet, amely a környezetvédelmi és természetvédelmi hatósági és igazgatási feladatokat ellátó szervek kijelölését végzi el. A rendelet több különböző kategóriába sorolja az érintett közigazgatási szerveket.

$22 \mathrm{Az}$ 1312/2016. (VI. 13.) Korm. határozat értelmében részben a minisztériumba, részben területi kormányhivatalokba olvadva szünik meg.

23 Fő szabály szerint egyébként a középszintü kormányhivatalok tekintendök a környezetvédelmi hatóságnak.

24 A 71/2015. (III. 30.) Korm. rendelet 9. § (1)-(2) bekezdései.

25 Fő szabályként itt is igaz, hogy a természetvédelmi hatóság elvben a területi kormányhivatal, ha a kormányrendelet ettől eltérően nem rendelkezik.

26 71/2015. (III. 30.) Korm. rendelet 20. § (1), valamint az 1312/2016. (VI. 13.) Korm. határozat.

27 71/2015. (III. 30.) Korm. rendelet 24-25. §.

28 Lásd többek között a Magyary Zoltán Közigazgatás-fejlesztési Programokat vagy legújabban a Közigazgatás- és Közszolgáltatás-fejlesztési Stratégiát.

29 További részletek olvashatók a Nagy Marianna-Hoffman István (szerk.) A Magyarország helyi önkormányzatairól szóló törvény magyarázata címủ munkában. HVG-Orac, Budapest, 2014, 33. 
tak..$^{30} \mathrm{~A}$ megyei önkormányzatok korábbi intézményfenntartó feladatai megszüntek, azok zömmel az államigazgatáshoz kerültek (egészségügyi, szociális, illetve köznevelési intézmények vándoroltak elöbb a megyei intézményfenntartó központokhoz, majd utóbb különböző dekoncentrált szervekhez). ${ }^{31} \mathrm{~A}$ járások felállításával számos további feladatátmozgatásra nyílt lehetőség (például a szociális igazgatásban vagy az építésügyi területen).

A jogalkotó célja ezzel összefüggésben az volt, hogy szorosabban integrálja az önkormányzatokat az államszervezetbe. Ennek folyományaként a területi típusú önkormányzataink a továbbiakban területfejlesztéssel és -rendezéssel, valamint vidékfejlesztéssel és az ezekkel összefüggő koordinációs feladatokkal foglalkoznak, az áthangszerelt önkormányzati rendszer alapszintje pedig elsősorban azokat a közszolgáltatásokat szervezi és nyújtja, amelyek a helyi közösség számára a legfontosabbak (mint a településtisztaság, helyi környezetvédelem, közvilágítás). ${ }^{32}$

A civil közigazgatás két nagy alrendszere közötti kapcsolatok újragondolásán (pl. törvényességi felügyelet bevezetése), ${ }^{33}$ valamint az önkormányzati rendszeren belüli feladatok átrendezésén túl (például fejlesztési feladatokra fókuszáló területi önkormányzatok létrehozása), az önkormányzatok belső viszonyai is módosultak. A képviselö-testület, polgármester, valamint jegyző relációjában egyértelmü változást idézett elő a polgármester operatív jogosítványainak a pontosítása, valamint az, hogy a hivatal vezetöjét a továbbiakban nem a testület, hanem a polgármester nevezi ki, illetve menti fel. ${ }^{34}$ Azzal párhuzamosan, hogy államigazgatási feladatoktól „fosztották meg” a települési jegyzőket, a jogalkotó megnyitotta annak lehetőségét, hogy - a korábbiaktól eltérően immár - a hivatal vezetője is dönthessen a hozzá utalt önkormányzati (hatósági) ügyekben. ${ }^{35}$

Amikor a továbbiakban - a fent írtakra tekintettel - kifejezetten az ökoszisztéma védelmével összefüggő feladatokat vizsgáljuk, leszögezhető, hogy a Kvt. a környezet védelme szempontjából releváns önkormányzati feladatokat a települési és területi típusú önkormányzatok kapcsán külön taglalja. Amíg a lakossággal való közvetlen feladatokat a települések látják el, addig a megyéknek inkább a tervezésben és az összehangolásban van szerepük. Ez a munkamegosztás jól tetten érhetö többek között abban, hogy a települések hatósági feladatokat látnak el, rendeleteket és határozatokat alkotnak, tájékoztatják a lakosságot a környezet állapotáról, valamint

30 Lásd Nagy-Hoffman: i. m., 35.

31 A megyei önkormányzati intézmények és a Fővárosi Önkormányzat egyes egészségügyi intézményeinek átvételéröl szóló 2011. évi CLIV. törvény, valamint a Klebelsberg Intézményfenntartó Központról és a Szociális és Gyermekvédelmi Igazgatóságokról szóló jogszabály.

32 Nem véletlen, hogy korábban is és a jelenlegi önkormányzati törvény definíciója szerint is a lakosság közszolgáltatásokkal való ellátása található a helyi közügy fogalmának első helyén. Lásd továbbá Horváth M. Tamás-Bartha lldikó (szerk.): Gyürük és sugarak. Mit nyújt egy magyar város? Dialóg Campus, Budapest-Pécs, 2014. Valamint Balázs István (szerk.): Helyi önkormányzatok. Debreceni Egyetemi Kiadó, Debrecen, 2014.

33 Nagy-Hoffman: i. m., 497.

34 Mötv. 67. § f) pont és 82. § (1) bek.

35 Mötv. 81. $\S(3)$ bekezdés i) pont. 
fejlesztéseik során is kötelesek a környezetvédelmi követelményeket érvényre juttatni. ${ }^{36}$ Ehhez képest a megyék alapvető rendeltetése az, hogy támogassák a helyhatóságok fenti feladatait (pl. azáltal, hogy véleményt nyilvánítanak a települések környezetvédelmi programjáról, vagy állást foglalnak a helyhatósági rendelettervezetek kapcsán). ${ }^{37}$

Amennyiben a településeken belüli munkamegosztásra vagyunk kíváncsiak, az ágazati kódex két önkormányzati szerv feladat- és hatáskörét bontja ki részletesen. Az egyik a képviselö-testület (a továbbiakban: KT), a másik a polgármester (a továbbiakban: PM). A KT kapcsán az egyik legfontosabb rendelkezést a 48. § (1) bek. tartalmazza, amely feljogosítja a testületeket arra, hogy - bizonyos korlátokkal - a központi jogszabályokban foglaltaknál szigorúbb környezetvédelmi elöírásokat is meghatározhassanak. ${ }^{38}$ Bár a Kvt. keretjogszabály, a jogalkotó már itt kiemelten foglalkozik - hatásköri vonatkozásban - a levegő mint környezeti elem védelmével. Erre tekintettel a testület hatáskörébe utalja a füstködriadó terv, a háztartási tevékenységgel okozott légszennyezésre vonatkozó egyes sajátos, valamint az avar és kerti hulladék égetésére vonatkozó szabályok rendelettel történő megállapítását. Továbbá logikailag az előbbiekhez tartozik még a légszennyezettség szempontjából ökológiailag sérülékeny területek kijelölésével kapcsolatos eljárásban való közremüködés. ${ }^{39}$

A PM-ről szintén a levegőtisztaság-védelmi feladatkör, illetőleg államigazgatási, hatósági hatáskör kapcsán tesz említést a törvény, hiszen az ő feladatává teszi a füstködriadó terv kidolgoztatását és végrehajtását, illetőleg az ennek végrehajtása során szükségessé váló kötelezések, korlátozások és felfüggesztések meghozatalát, mint ahogy külön jogszabályban meghatározott szmoghelyzet (füstköd) bekövetkezése esetén az érintett lakosság tájékoztatását. ${ }^{40}$

Utalunk továbbá a társulásokra, mint az önkormányzatok közös feladatellátásának közjogilag szabályozott intézményeire, amelyek a környezet védelmét elösegítő feladatok ellátásában ugyancsak fontos szereppel rendelkezhetnek (például a hulladékgazdálkodási feladatok közös ellátásában, környezeti viták rendezésében).

Nem szabad ugyanakkor elfelejteni, hogy a környezet védelmében a társadalmi részvételnek, az önkormányzatokkal kapcsolatba kerülő civilszervezeteknek is komoly szerepük van. Ennek hangsúlyozása amiatt különösen fontos, mert az esetek nagy részében eleve az önkormányzatok tudják/tudnák ilyen irányú feladatukat a legkönnyebben és leghatékonyabban biztosítani, hiszen ők vannak legközelebb a potenciális érdekeltekhez. A hatályos Mötv. (Magyarország helyi önkormányzatairól szóló 2011. évi CLXXXIX. törvény) - a fentebb ismertetett eszközökön túl - több olyan lehetöséget is nevesit, amelyen keresztül maguk az érintettek müködhetnek

36 Kvt. 46. $\S(1)$.

37 Kvt. 46. § (2).

38 Ennek feltételeit az Alkotmánybíróság több összefoglaló jellegü döntésében részletesen körülírta. Ezzel kapcsolatban lásd BÁNDI Gyula: Környezetvédelmi kézikönyv. KJK-Kerszöv, Budapest, 2000, 115; valamint FOdOR (2016) i. m., 355-359.

39 Kvt. 48. § (4).

40 Kvt. 48. $\S(6)$. 
együtt a helyhatósággal (például a szervezeti és müködési szabályzatban rendezhető, hogy mely társadalmi szervezetnek van tanácskozási joga a KT, illetve bizottság ülésén). Ugyancsak az SZMSZ rendezi azoknak a fórumoknak a körét és müködési rendjét, amelyek az információk (tehát akár környezetvédelmi relevanciájú információk) megosztását szolgálják (mint a falugyülés). ${ }^{41}$ Ezekkel a megoldásokkal természetszerüleg lehetséges környezeti szempontoknak, céloknak a becsatornázása is az önkormányzat müködésébe.

Az önkormányzatokra háruló környezetvédelmi kötődésű feladatok köre azonban ettöl tágabb, amit a Mötv. is alátámaszt. A jogszabály 13. §-a több, kifejezetten környezetvédelmi relevanciájú feladatot is nevesít, ilyen például a településfejlesztés és -rendezés, a környezet-egészségügy, a helyi környezet- és természetvédelem, a hulladékgazdálkodás vagy a víziközmü-szolgáltatás. A kép azonban ettöl még árnyaltabb, mivel a Mötv. felsorolását más ágazati törvények további, kötelező feladatokkal bövítik. ${ }^{42}$ Ezek egyes esetekben látszólag nem is kifejezetten környezetvédelmi irányultságú jogszabályok, mint ahogy az a „Hatásköri törvény” néven ismert jogforrás esetén is tetten érhető, amely a KT feladat- és hatáskörébe utalja a helyi zaj- és rezgésvédelmi szabályok megállapítását éppúgy, mint a környezetvédelmi alappal való rendelkezést és gazdálkodást. ${ }^{43}$

A fentiek alapján elkészíthető a környezet- és természetvédelmi feladatokat ellátó intézményrendszer sémája, amely a megnevezett közigazgatási szerveken kívül tartalmazza azokat az aktorokat is, amelyeknek kapcsolódó jogosítványai vannak, illetve amelyek ugyan nem állami szervek, de közremüködésük nélkülözhetetlen ezen a területen.

41 Erre egyébként a Kvt. is kifejezetten felhívja az önkormányzatokat.

42 A teljesség igénye nélkül utalunk itt a hulladékról szóló 2012. évi CLXXXV. törvényre, a 2003. évi LXXXIX. törvényre, amely a környezetterhelési díjról rendelkezik, az 1996. évi LIII. törvényre, amely a természet védelméről szól.

43 1991. évi XX. törvény a helyi önkormányzatok és szerveik, a köztársasági megbízottak, valamint egyes centrális alárendeltségű szervek feladat- és hatásköreiröl. 85. § (1) bekezdés c), d), e), i) pontok. De ugyancsak ebbe a körbe sorolható a csődeljárásról és a felszámolási eljárásról szóló 1991. évi XLIX. törvény. 
1. táblázat. A magyar környezetvédelmi intézményrendszer sémája 2016-ban

\begin{tabular}{|c|c|c|c|}
\hline & $\begin{array}{l}\text { ÁlLAmIGAZGATÁs } \\
\text { (tervezés és hatósági feladatok) }\end{array}$ & \begin{tabular}{|l} 
HELYI \\
öNKORMÁNYZATOK \\
(tervezés, közre- \\
müködés, értéke- \\
lés, jelzés)
\end{tabular} & $\begin{array}{l}\text { NEM ÁLLAMı } \\
\text { SzERVEK } \\
\text { (kÖzremüködés, } \\
\text { véleményezés, } \\
\text { érdekképviselet) }\end{array}$ \\
\hline $\begin{array}{l}\text { KöZPONTI } \\
\text { SZINT }\end{array}$ & $\begin{array}{l}\text { Kormány } \\
\text { Országos Környezetvédelmi Tanács } \\
\text { Földmüvelésügyi miniszter, } \\
\text { belügyminiszter, } \\
\text { nemzeti fejlesztési miniszter } \\
\text { Országos Környezetvédelmi } \\
\text { és Természetvédelmi Főfelügyelöség } \\
\text { (2017. 01. 01-ig) } \\
\text { Országos Vízügyi Főigazgatóság } \\
\text { Országos Katasztrófavédelmi } \\
\text { Főigazgatóság } \\
\text { Herman Ottó Intézet (2017. 01. 01-ig) }\end{array}$ & & \multirow{3}{*}{$\begin{array}{l}\text { civilszervezetek, } \\
\text { közhasznú } \\
\text { alapítványok, } \\
\text { egyesületek }\end{array}$} \\
\hline $\begin{array}{l}\text { TERÜLETI } \\
\text { SZINT }\end{array}$ & $\begin{array}{l}\text { Fővárosi, megyei kormányhivatalok } \\
\text { Vízügyi igazgatóságok } \\
\text { Nemzetipark-igazgatóságok } \\
\text { Járási hivatalok } \\
\text { Herman Ottó Intézet területi } \\
\text { igazgatóságai (2017. 01. 01-ig) }\end{array}$ & $\begin{array}{l}\text { Megyei } \\
\text { önkormányzatok }\end{array}$ & \\
\hline $\begin{array}{l}\text { TELEPÜLÉSI } \\
\text { SZINT }\end{array}$ & & $\begin{array}{l}\text { Települési } \\
\text { önkormányzatok } \\
\text { [(fő)polgármester, } \\
\text { (fő)jegyző] }\end{array}$ & \\
\hline
\end{tabular}

\section{Egyes környezetvédelemhez kapcsolódó szakigazgatási területek alakulása az önkormányzati feladatrendszerben}

A környezetvédelem ún. horizontális területnek tekinthetö, amelynek szempontjait „a gazdaságpolitikai döntések kialakítása, a terület- és településfejlesztés, a regionális tervezés, továbbá a nemzetgazdaság bármely ágában megvalósuló állami tervezési és végrehajtási tevékenység során érvényre kell juttatni”. ${ }^{44}$ A kapcsolódó területek vizsgálata melletti érvként hozható fel az a tendencia is, amely az állam (kormányzat) több szektort érintő centralizációs törekvésével azonosítható; elegendő ebben a körben a megyei önkormányzatok szerepének „újratervezésére” vagy éppen a területi államigazgatás kompetenciáinak erősödésére gondolni. Ezzel öszszefüggésben kiemelhető, hogy az átalakítások mögött néha inkább fiskális megfontolások rejlenek, mintsem az elvontabb értékek (mint a környezetvédelem, fenntarthatóság) realizálása, avagy az igazgatás tárgyának valamilyen speciális szük- 
séglete. ${ }^{45}$ Ezt felismerve - igazodva a környezetvédelmi jog integratív jellegéhez - a következőkben a környezetvédelem témaköréhez kapcsolódó szektorális kérdések közül a településfejlesztés, valamint az építésügyi igazgatás területén bekövetkezett, fontosabb változásokat érintjük.

\subsection{Néhány gondolat a településfejlesztés környezetvédelmi szempontjaihoz}

Bár a települések rendezett fejlesztésének (és ezzel szoros összefüggésben a térfelhasználásnak ${ }^{46}$ ) a lakóhelyünkre, környezetünkre pozitív és negatív hatásai egyaránt lehetnek, témánk szempontjából legalapvetőbb célja, hogy a beruházások megkezdése előtt, preventív jelleggel gyakoroljon hatást, valamint lehetőség szerint minimalizálja a környezetterhelést, a jó minőségü és biztonságos környezet érdekében. ${ }^{47}$ Terjedelmi korlátok miatt itt és most csak arra utalunk, hogy a legfontosabb, stratégiai jellegü kérdések (pl. településfejlesztési koncepció, környezetvédelmi program elfogadása) az önkormányzat választott testülete előtt dőlnek el ${ }^{48}$ Persze a döntések előkészítésében, illetve azok végrehajtásának kontrolljában már sokszor a bizottságok vesznek részt. Miután pedig a településfejlesztés és a környezetvédelem is integratív, több ágazaton átível, azokat összekapcsolja, ${ }^{49}$ nem meglepö, hogy számos esetben ez a két terület egymásba oltva jelenik meg a helyhatósági munkában (lásd példaként Nyíregyházát, ahol Városstratégiai és Környezetvédelmi Bizottság múködik, vagy Budakalászt, ahol Településfejlesztési és Környezetvédelmi Bizottság müködik, illetve Eger városát, ahol Városképi és Környezetvédelmi Bizottság elé tartoznak az ilyen kérdések).

Mivel az önkormányzati testületek időszakos müködésüek, nélkülözhetetlen az olyan operatív szervek közremüködése, mint a polgármester vagy a polgármesteri (közös önkormányzati) hivatal, illetve az azt vezető jegyző. A fentebb már taglalt feladatok újbóli megismétlésének elkerülése érdekében ezen a helyen csak arra utalunk, hogy - korlátokkal ugyan, de - a testület nem csupán döntési jogokat ruházhat át a polgármesterre és a jegyzőre, hanem a hatályos szabályok alapján a polgármester bizonyos helyzetekben a testület helyett dönthet is. ${ }^{50} \mathrm{~A}$ jegyző (esetenként járásszékhely települési önkormányzat jegyzője) pedig az egyes döntések szakmai

45 Példának okáért a hulladékgazdálkodásban bekövetkezett változtatásoknak inkább a hazai és uniós közpénzek felhasználásához, illetve egyes érdekcsoportok lobbitevékenységéhez van köze, mintsem a környezet védelméhez.

46 A településrendezésröl ezen a helyen külön nem lesz szó. A szorosan kapcsolódó terület fontosságára ugyanakkor jól rávilágít többek között Fodor (2016): i. m., 362, valamint az, hogy a rendelkezésre álló tér felhasználásának, a harmonikus települési közegnek milyen nagy jelentőséget tulajdonít a jogalkotó is, legújabban a településkép védelméröl szóló 2016. évi LXXIV. törvényben.

47 BÁNDI (2014): i. m., 423.

48 További részletek olvashatók itt: BARTA Attila: Településfejlesztés, infrastruktúra-fejlesztés. NKE, Budapest, 2016.

49 Fodor László: Környezetjog. Debreceni Egyetemi Kiadó, Debrecen, 2014, 116.

50 Mötv. 68. § (2)-(4). 
előkészítésén túl konkrét hatósági jogkörein keresztül is kapcsolódhat a településfejlesztéshez és a környezetvédelemhez, úgymint ipari, kereskedelmi, építésügyi és természetvédelmi ügyekben. ${ }^{51}$

\subsection{Környezetvédelmi szempontból releváns változások az építésügyi igazgatásban}

Vitathatatlan, hogy az építésügy - közelebbröl a településrendezés és az építésrendészet realizálása - több ponton is kapcsolódik a környezethez, mivel a településkép kialakítása, egyes létesítmények engedélyezése, az építési munkálatok végzésére vonatkozó központi és helyi követelmények közvetlenül és közvetve is számottevő hatást gyakorolnak a környezetre. Megjegyezzük azonban, hogy a tapasztalatok fényében a hazai építésügyi politika kissé lyukacsosnak, néhol ötletszerünek tekinthetö. ${ }^{52}$

Az építésügy - szükebben értelmezve az építési tevékenység - és a környezet egymásra hatását egyértelművé teszi az épített környezet kialakításáról és védelméről szóló 1997. évi LXXVIII. törvény (a továbbiakban: Étv.), amikor akként rendelkezik, hogy „[a]z épitmény elhelyezése során biztositani kell [...] a környezetvédelem és a természetvédelem sajátos követelményeit és érdekeit". ${ }^{53}$ Ennek megfelelöen az építésügy és a környezetvédelem komplex összefüggésrendszert eredményez, amelynek komponensei közül ezen a helyen csak azokat a jogintézményeket érintjük, amelyek a jogalkotás legújabb fejleményei következtében kerültek be a regulációba.

A Kormány tavaly fogadta el az építésügy átalakítását célzó intézkedési tervröl és az ahhoz kapcsolódó feladatokról szóló 1567/2015. (IX. 4.) Korm. határozatot, amely három beavatkozási területet azonosított az újraszabályozás tekintetében: a lakossági építkezésekhez kapcsolódó bürokráciacsökkentést, a tervezőkre vonatkozó szabályozás átalakítását, valamint a szerzői jogi szabályozás - kapcsolódó - módosítását. A lakossági építkezésekre irányadó „bürokráciacsökkentés” realizálása érdekében nevesített intézkedések közül két tervezett módosítást emelünk ki. A Kormány - szervezeti értelemben - elvi éllel döntött amellett, hogy - igazodva a területi államigazgatásban az elmúlt években véghez vitt és a továbbiakban is fenntartandónak ítélt integrációhoz - „[a]z ügyintézés hatékonyabbá tétele érdekében az általános épitésügyi hatósági hatáskört a jegyzőtől a járási hivatalba kell integrálni”. ${ }^{44}$ Ez a változtatási irány lényegében az építésrendészet lokális kapcsolódását

51 A hatályos környezetvédelmi jogosítványok táblázatba rendezett áttekintése megtalálható a Belügyminisztérium által időszakonként kiadott hatásköri jegyzékben.

52 Példának okáért a Közigazgatás- és Közszolgáltatás-fejlesztési Operatív Program (a továbbiakban: KÖFOP) az „integrált területfejlesztési megközelítés” keretében igénybe vehető eszközök között nem tervezi a közösségvezérelt helyi fejlesztés és a fenntartható városfejlesztés alkalmazását. Ehhez lásd: http://nhit. hu/dokumentum/117/KOFOP_10_0.pdf (2016. 07. 11.).

53 Étv. 31. § (1) bek. c) pont.

54 1567/2015. (IX. 4.) Korm. határozat 1.1. pontja. 
csökkenti, a jegyzői hatáskörnek a járási hivatal vezetője kompetenciájává konvertálása (tovább) szükíti az önkormányzati építésügy terrénumát.

Szükséges továbbá szólni a lakossági építkezések megkönnyítését célzó intézkedésröl, amely a bejelentési elv térnyerését kívánja realizálni az engedélyezési eljárásokkal szemben. A hivatkozott kormányzati döntés értelmében a legfeljebb $160 \mathrm{~m}^{2}$ hasznos alapterületü lakóépület építése (valamint a meglévő lakóépület legfeljebb $160 \mathrm{~m}^{2}$ hasznos alapterületüvé történő bővítése vagy átalakítása) esetén az építésügyi hatóságnak tudomásulvételi eljárást kell lefolytatnia, amennyiben szakhatósági közremüködés és építésügyi követelmények vizsgálatán túlmenő szakkérdés vizsgálat nem szükséges. A kormányhatározatban foglalt elképzelésen azonban a jogalkotó kissé túllépett, mivel az Étv. módosítása a legfeljebb 300 négyzetméter összes hasznos alapterületủ új lakóépület építése esetén tette fő szabállyá az egyszerü bejelentési kötelezettséget az engedélyezési eljárás helyett. ${ }^{55} \mathrm{E}$ helyütt annyit jelzünk, hogy ez a módosítás alapvető profilváltást igényel az építési igazgatásban részt vevő hatóságoktól, mivel az előzetes engedélyezési tevékenység ${ }^{56}$ helyett a bejelentési kötelezettséggel kombinált utólagos kontroll eszközrendszerével lesz teljes körűen biztosítandó a jövőben az építési munkálatok jogszerűsége, szakszerüsége és biztonságossága, illetve ezen keresztül a környezeti szempontok érvényesülése.

\section{3. Összegzés, következtetések}

Az elmúlt évtizedek ráirányították a figyelmet arra, hogy a szektorális szemléletü megközelítés globális problémákra (a klímaváltozásra, a légszennyezésre, a hulladékokkal kapcsolatos problémákra, valamint ezek elsődleges és másodlagos negatív hatásaira) adott válaszai elégtelenek ${ }^{57} \mathrm{~A}$ hatékony védelem érdekében mind nagyobb szerep hárul a közigazgatási szervekre, valamint a civil szféra és a gazdasági szektor szereplőire, illetve hatékony együttmüködésükre..$^{58}$

Ami az Alaptörvényt illeti, komplex szemlélete megfelelő keretet biztosít ehhez. Az „alkotmányos környezetjog” a környezethez való jogot olyan alapjognak tekinti, amely az emberi élethez való jog fizikai feltételeit hivatott biztosítani, lényegében annak objektív, intézményi oldalának része. Éppen emiatt egyfelöl különösen nagy jelentősége van a prevenciónak, ${ }^{59}$ másfelöl viszont az állami szervek aktív jelenléte kívánatos annak érdekében, hogy az intézményvédelmi oldal jól müködjön. Az Alaptörvénynek a környezetvédelemhez kapcsolódó vagy kapcsolható rendelkezései mindenképpen elörelépést jelentenek, ebben a körben az emberi méltóság kiterjesztett értelmezése, a felelősségi, kötelezettségi oldal kidomborítása, a jövő generációk védelmének a megjelenítése az Alaptörvény előnyeként emelhető ki. ${ }^{60}$

${ }_{55}$ Étv. 33/A. §.

${ }^{56} \mathrm{Az}$ épitésrendészet korábbi rezsimjének áttekintéséhez lásd KóвоR Gyula: Az épitésügy igazgatása. In: Bencsik András (szerk.): Közigazgatási jog. Különös rész l. Dialóg Campus Kiadó, Budapest-Pécs, 2014, 100-104.

57 Kilényi: i. m., 1219.

58 Erre vonatkozóan lásd még: FöLDI László-HaLÁsz László: Környezetbiztonság. CompLex, Budapest, 2009.

59 28/1994. (V. 20.) AB határozat.

60 BÁndI: A környezethez való jog értelmezése... (2013) i. m., 88. 
Látható, hogy a környezethez való viszonyulás tekintetében a közigazgatási jognak olyan, más szakigazgatási területeken nem feltétlenül megjelenő elvekre kell támaszkodnia, mint a megelőzés, az integráció vagy a tervszerüség. ${ }^{61}$ Bár a szabályozási módszerek tekintetében is a sokszínüség jellemző, az egyik legmeghatározóbb mind a mai napig a közigazgatás direkt beavatkozása (például közhatalom birtokában kötelezésekkel, korlátozásokkal, szankciókkal). ${ }^{62}$

A helyzet komplexitását csak fokozza a szabályozási tárgykörök heterogenitása, ugyanis a környezetjogi szakirodalomban az általános szabályokon túl, a környezetjog ún. különös részéhez sorolható a területfejlesztés és -rendezés, az épített környezet alakítása és védelme, valamint a településfejlesztés és -rendezés, a föld-, természet-, levegőtisztaság-, zajártalom és rezgések elleni védelem, valamint a vízvédelem, illetve a hulladékgazdálkodás, a veszélyes anyagok és az ipari baleseti kockázatok kezelését rendező szabályok. ${ }^{63}$ Nyilvánvaló, hogy ezek a területek egymástól sokszor igen eltérő szabályozási logikát és eszközöket kívánnak meg a közigazgatástól.

A környezetvédelem ágazati kódexe, a Kvt. megfogalmazása szerint a környezet védelme az állam és a helyi önkormányzatok közös feladata, a részleteket vizsgálva azonban egyértelmű, hogy a súlypont mégis az állami/államigazgatási felelősségi körökre helyeződik. Magyarországon a környezetvédelmi igazgatás és eszközrendszer alapvető jellemzője a centralizáció. A helyhatóságok szabályozási, valamint hatósági jogköreit vizsgálva rögzíthetö, hogy - egyes közhatalmi jogosítványoktól eltekintve - elsősorban „soft” eszközökkel rendelkeznek, azaz jellemzően nagyobb hálózatok, együttmüködések résztvevői, semmint kizárólagos szereplői lehetnek a környezet védelmét szolgáló intézkedéseknek. ${ }^{64}$ Áttekintve a környezetvédelmi relevanciájú feladatokat, egyensúlyhiányra, valamint hatásköri aszimmetriára figyelhetünk fel.

A központi közigazgatási szerveknek a környezetvédelem területén érvényesülö kompetenciáival összefüggésben rögzíthető, hogy a szabályozás inkább szól a környezetvédelmi politika alakításával kapcsolatos prioritásokról, beavatkozási területekröl és eszközökről, mintsem a környezetvédelmi igazgatás ágazati irányításáról. Megjegyzendö az is, hogy a környezetvédelem központi szervezése (értsd minisztériumi "hovatartozása”) nagy fokú dinamizmust mutat a rendszerváltás óta eltelt időszakban. Ez abból a szempontból kifogásolható, hogy a terület ágazati föhatóságának gyakori (időnként kifejezetten ötletszerủen történő) változása megnehezítheti az egységes, ciklusokon átívelő környezetvédelmi politika tartalmi kontinuitását.

Az önkormányzatok mozgásterén érdemben a Mötv. sem változtatott a korábbiakhoz képest. A helyi önkormányzatok saját, önálló hatáskörrel alig rendelkeznek, szerepük a központi államtól átruházott jogkörben történő közremüködés, vagy számos esetben osztott hatáskörben való eljárás. A jelenlegi közigazgatási jogi szabályozás,

61 Lásd még BÁNDI Gyula: Környezetjog. Szent István Társulat, Budapest, 2014, 27-92 [a továbbiakban: BÁNDI (2014)].

62 BÁndi (2014): i. m., 268; valamint a további részleteket lásd GelLérTheGYI István: Az engedély szerepe a környezetvédelemben. HVG-Orac, Budapest, 2009.

${ }^{63}$ BÁNDI (2014): i. m., 419, valamint Kilényi: i. m., 1220.

${ }^{64}$ Az önkormányzati együttmüködések hazai és nemzetközi lehetöségei kapcsán lásd még: http://uni-nke. hu/uploads/media_items/2016_-evi-5_-szam-onkormanyzati-halozatosodas-europaban-magyarorszagivonatkozasok.original.pdf (2016. 08. 11.). 
így például ${ }^{65}$ a helyi környezet- és természetvédelem, valamint vízgazdálkodás és vízkárelhárítás nevesített feladatain túl az egyre égetőbbnek tekinthető klímavédelem nem jelenik meg. Ugyanakkor indirekt módon, a településfejlesztésen és -rendezésen keresztül érvényre juttathatók klimatikus célok és szempontok.

Nincs ez másként az építésügyben sem, hiszen a természeti mellett az épített környezet védelme is szerves kötődést mutat a vizsgált területtel. Korábban tettünk utalást arra, hogy alapvető "újratervezés” zajlik az épitésügyi szakigazgatásban, amelynek legérzékelhetőbb megnyilvánulása az állami kontroll átalakulása a lakossági építkezések megkönnyítése érdekében. Jelen tanulmány fókuszpontjára tekintettel röviden indokolt szólni arról, hogy a hatósági jogalkalmazás eszközrendszerében bekövetkező szükségszerü profilváltás mellett az új szabályozás (közelebbröl az épitési tevékenység előzetes kontrolljának részleges megszünése) magában hordozza olyan épitkezések megkezdésének lehetöségét is, amelyek nem (minden tekintetben) felelnek meg a törvényességi, biztonságossági és szakszerüségi követelményeknek. Tekintettel arra, hogy az egyszerü bejelentési eljárás nem teszi az építési munkálatok megkezdésének előfeltételévé az előzetes engedélyezést, a közigazgatás kénytelen lesz megtalálni azokat az eszközöket, amelyek által az építésügy funkciói az új szabályozási környezetben is realizálhatók.

Végezetül azt is megjegyezzük, hogy a jogalkotó eljárási vonatkozásban is célul tủzte ki az építési jog reformját, mivel a már hivatkozott kormányhatározat megfogalmazta azt az elvárást, hogy a készülő általános közigazgatási rendtartásról szóló törvény legyen tekintettel az építésügyi igazgatásban érvényesülő sajátosságokra. Ezzel összefüggésben megjegyzendö, hogy egyrészt sajátosnak tekinthető az a megközelítés, amikor a jogalkotó egy készüló új, általános érvényü eljárási kódex megalkotásakor egy, kiemelt szakigazgatás speciális eljárási szabályainak „fokozott figyelembevételét" írja elő, másrészt érzékelhető az a prioritás, amivel a kormányzat az építési igazgatás fejlesztéséhez viszonyul, beleértve annak szervezeti, müködési és személyzeti összetevőit egyaránt.

\section{Abstract}

This study investigates the transformation of environmental protection as a specialized administrative duty in Hungary, with special attention on the (changing) roles of local self-governments in this area. Following the outline of the general correlations within the topic, the study inspects several individual administrative fields, with attention given to the relationship with environmental protection policies. Our plan is to extend this analysis in the future, in hopes of covering additional specialised administrative areas as well. Our firm opinion is that the solutions provided by the sectorial approach inherent in our administrative system proved to be ineffective insolving today's global issues. To ensure an effective environmental protection strategy, the organizations of public administration must be involved with larger roles assigned to them. Although the methods of regulation in this area are diverse, the most widespread approach proves to be the direct administrative intervention, even nowadays.

65 Mötv. 13. §. 